\title{
Journal of Medical Microbiology \& Diagnosis
}

\section{Is it Possible that an Acute Demyelinating Encephalitis at an Adult 38 Years Old to be Caused by Adenovirus?}

\section{Cristina Tecu* and Vasilica Ungureanu}

Senior Physician in Microbiology, National Institute Research and Development for Microbiology and Immunology Cantacuzino, Bucharest, Romania

I wrote this letter that in research literature I found some papers which describe the presence of encephalitis caused by different types at adenovirus at children, but no in adults. So, I presented in this letter the situation of a young adult that might be done a meningoencephalitis caused by adenovirus.

Patient aged 38 years with obesity is admitted in infectious diseases hospital Constanta with diagnosis of bilateral lower lobar bronchopneumonia (debut date Oct/3/2014) and symptoms: fever, fatigue, malaise, myalgia, headache, cough, sputum, and dyspnea. After the diagnosis of pulmonary Radioscopy the physician put the admission diagnosis (lobar consolidation). It establishes treatment with cephalosporins (Cefort) without be made the antimicrobial susceptibility. None viral investigations were is done. The symptoms worsen; the patient became agitated, with altered level of consciousness, hallucinations and meningeal signs.

He was transferred to Emergency Hospital Bucharest on oct.09.2014, the department of ICU in a coma. It performed the four MRI examinations and diagnosis was of acute demyelinating encephalitis. The WBC counts showed an increase of neutrophils and of C-reactive protein (CRP).

The patient is intubated and mechanically ventilated. It establishes treatment with Tamiflu, Acyclovir, Meropenem, and Linezolid. On oct.15, 2014, tracheobronchial aspirate is harvested and sent to NIRDMI Cantacuzino for the diagnosis of influenza virus A/H1N1 and Haemophilus influenzae. The patient was not vaccinated against flu and Haemophilus influenza. The test results were negative (also included the diagnosis for Meningococcus and Streptococcus pneumonia), but in the Laboratory of Respiratory Viral Infections is also performed the RT-PCR Detection with Kit OneStep ACE Seeplex (Seegene) for 13 other respiratory viruses. Only the traheo-bronhial aspirate was collected and no CSF sample.

The result of the reaction: positive for Adenovirus Figure 1 (Patient no.1203-1871). After that, the authors did not do the genogrouping and serotyping of sample.

The question that was asked was which was bacterial or viral infection which determined the meningoencephalitis at this patient. Adenoviridae are rare cause's meningoencephalitis. It was reported [1] that serotype 26 could cause adenoviral meningoencephalitis in immunocompromised hosts.

Anyway Human Adenovirus can mimic severe bacterial infections due to the presence of high-grade pyrexia associated with significantly elevated acute phase reactants [2].

Another case of meningoencephalitis due to adenovirus in a healthy infant and mimicking severe bacterial sepsis was recently described by Joaquin Reyers-Andrade et al [3].

From another point of view Charles Gabbert et al. [4] and other researchers showed an association of obesity and higher body weight with the presence of neutralizing antibodies to AD36 in children. So, is it possible in this case that meningoencephalitis was caused by Adenovirus?

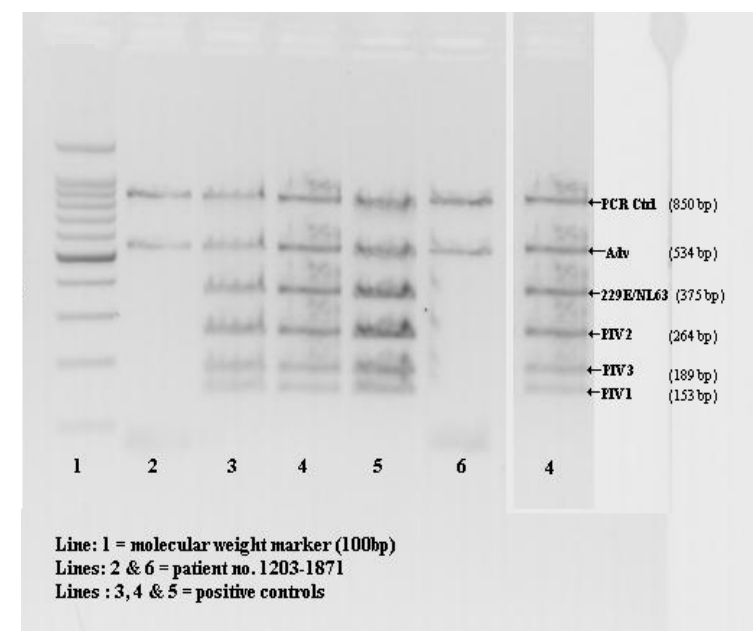

Figure 1: The result of the reaction for Adenovirus.

\section{References}

1. Dubberke ER, Tu B, Rivet DJ, Storch GA, Apisarnthanarak A, et al. (2006) Acute meningoencephalitis caused by adenovirus serotype 26 . J Neurovirol 12: $235-240$.

2. Chuang Yu, Chiu CH, Wong KS, Huang JG, Huang YC, et al. (2003) Severe adenovirus infection in children. J Microbiol Immunol Infect 36: 37-40.

3. Reyers-Andrade $\mathrm{J}$ (2014) Meningoencephalitis due to adenovirus in a healthy infant mimicking severe bacterial sepsis". The Pediatric Infect. Disease Journal 33:4.

4. Gabbert C, Donohue M, Arnold J, Schwimmer JB (2010) Adenovirus 36 and obesity in children and adolescents. Pediatrics 126: 721-726.

*Corresponding author: Cristina Tecu, Senior Physician in Microbiology, Senio Researcher II, National Institute Research and Development for Microbiology and Immunology Cantacuzino, Bucharest, Romania, Tel: +40749032041; E-mail: tecucristina@yahoo.com

Received November 10, 2014; Accepted March 15, 2015; Published March 17 2015

Citation: Tecu C, Ungureanu V (2015) Is it Possible that an Acute Demyelinating Encephalitis at an Adult 38 Years Old to be Caused by Adenovirus?. J Med Microb Diagn 4: 180. doi:10.4172/21610703.1000180

Copyright: (C) 2015 Tecu C, et al. This is an open-access article distributed unde the terms of the Creative Commons Attribution License, which permits unrestricted use, distribution, and reproduction in any medium, provided the original author and source are credited. 